\title{
Radiation-Chemical Degradation of Oxalic Acid in Water Solutions
}

\author{
Muslim Gurbanov, Ulviyye Guliyeva, Sahib Mammadov* and Hokman Mahmudov \\ Institute of Radiation Problems, Azerbaijan National Academy of Sciences, Baku Az1143, Azerbaijan
}

\begin{abstract}
Co}^{60}$ gamma ray radiolysis of aqueous oxalic acid solution $\left(1 \times 10^{-2} \mathrm{M}\right)$ was investigated within the dose range up to 80 $\mathrm{kGy}$. The value of $\mathrm{pH}$ increases from 2.0 to 4.0 and approximately $90 \%$ of oxalic acid and its derivatives are degraded at the dose of $80 \mathrm{kGy}$. Dissolved $\mathrm{O}_{2}$ affects to the degradation of oxalic acid at the initial stage due to total consumption of $\mathrm{O}_{2}$ at the dose of $2 \mathrm{kGy}$. Formation of $\mathrm{CO}_{2}$ occurs at a higher rate at the initial stage until the dissolved $\mathrm{O}_{2}$ is fully consumed. The kinetic model of oxalic acid degradation in aqueous solution under the gamma irradiation was tested. The suggested mechanism complies with the experimental data both of our own and of that reported earlier.
\end{abstract}

Key words: Oxalic acid, $\gamma$-irradiation, kinetic model, radiation-chemical yield.

\section{Introduction}

Oxalic acid is one of the proposed intermediate products in the multistage phenol degradation into $\mathrm{CO}_{2}$ under the ionizing irradiation of aqueous solution [1]. On the other hand, radiation-chemical conversion of liquid radioactive waste significantly predefines their safe storage. Consequently, detailed knowledge of the processes interlining the radiolysis of oxalic acid which is one of the components of liquid radioactive waste remains still of interest. Radiation chemical degradation of oxalic acid produces long row of organic acids and gaseous products like $\mathrm{CO}_{2}$ and $\mathrm{H}_{2}$ [2]. Radiolysis of aqueous solutions of oxalic acid has been previously investigated [2-4], but they cover either the initial or late stages of oxalic acid degradation. However, there is no systematic investigation covering wide range of absorbed irradiation dose, which makes it difficult for proper understanding the mechanism of radiolysis of aqueous oxalic acid solution and consequently the mechanism of complete phenol degradation into $\mathrm{CO}_{2}$ and $\mathrm{H}_{2} \mathrm{O}$ as well as utilization and safe storage of

\footnotetext{
"Corresponding author: Sahib Mammadov, Ph.D., research filed: radiation chemistry. E-mail: mammadov_sahib@yahoo.com.
}

liquid radioactive waste.

In the current study the radiolysis of aerated aqueous solution of oxalic acid has been investigated at the wide range absorbed gamma irradiation dose covering its initial conversion as well as the final stage of deep oxidation.

\section{Experimental Sections}

Aerated $\left(\left[\mathrm{O}_{2}\right]=2.7 \times 10^{-4} \mathrm{M}\right)$ aqueous oxalic acid solution $\left(1 \times 10^{-2} \mathrm{M}\right)$ was irradiated by $\mathrm{Co}^{60}$ gamma rays at the static condition in sealed glass vials at room temperature. The dose rate was $0.22 \mathrm{~Gy} / \mathrm{s}$ which was determined by ferrous sulfate dosimeter, $\mathrm{pH}$ with $\mathrm{pH}$ meter PHS-25, $\mathrm{KMnO}_{4}$ (potassium permanganate) was used for measuring COD (chemical oxygen demand). $\mathrm{CO}_{2}$ was analyzed by a gas chromatography.

\section{Results and Discussion}

To create the model of oxalic acid radiolysis, the authors applied the schema of the reactions fully describing the radiolysis of water [5]. The following preconditions were taken into account at the computer modelling of radiolysis applied to the aerated aqueous oxalic acid solution: Oxalic acid concentration $=1 \times$ 
$10^{-2} \mathrm{M}$ and concentration of dissolved $\mathrm{O}_{2}=2.7 \times 10^{-4}$ M. The dose rate $0.22 \mathrm{~Gy} / \mathrm{s} ; \mathrm{pH}=1-4$, radiation-chemical yield of water radiolysis products as in Table 1.

The following list of reactions (Table 2) was selected as the most appropriate to describe the experimental data both of our own and of that reported earlier.

The results of calculations demonstrated in Figs. 1 and 2, and compared with the experimental data.

Table 1 The radiation chemical yields (G) of water radiolysis products.

\begin{tabular}{lllllll}
\hline Intermediate products & $\mathrm{H}^{+}$ & $\mathrm{OH}$ & $\mathrm{e}_{\mathrm{aq}}$ & $\mathrm{H}$ & $\mathrm{H}_{2}$ & $\mathrm{H}_{2} \mathrm{O}_{2}$ \\
\hline $\mathrm{G}$ (molec/100ev) & 3.45 & 2.49 & 3.05 & 0.6 & 0.425 & 0.8 \\
\hline
\end{tabular}

Table 2 The list of reactions considered at the modelling of aqueous oxalic acid solution radiolysis.

\begin{tabular}{|c|c|}
\hline Reactions & $\begin{array}{l}\mathrm{K}, \\
\mathrm{L} / \mathrm{M} \cdot \mathrm{s}\end{array}$ \\
\hline 1. $\mathrm{HOOCCOOH}=\mathrm{H}^{+}+\mathrm{HOOCCOO}^{-}$ & $5.6 \times 10^{8}$ \\
\hline 2. $\mathrm{H}^{+}+\mathrm{HOOCCOO}^{-}=\mathrm{HOOCCOOH}$ & $1 \times 10^{10}$ \\
\hline 3. $\mathrm{HOOCCOO}^{-}=\mathrm{H}^{+}+\mathrm{OOCCOO}^{-}$ & $5.4 \times 10^{5}$ \\
\hline 4. $\mathrm{H}^{+}+{ }^{-} \mathrm{OOCCOO}^{-}=\mathrm{HOOCCOO}^{-}$ & $1 \times 10^{10}$ \\
\hline 5. $\mathrm{e}+\mathrm{HOOCCOOH}=(\mathrm{HO})_{2} \mathrm{CCOOH}+\mathrm{OH}^{-}$ & $2.5 \times 10^{10}$ \\
\hline 6. e $+\mathrm{HOOCCOO}^{-}=(\mathrm{HO})_{2} \mathrm{CCOOH}+2 \mathrm{OH}^{-}$ & $3.2 \times 10^{9}$ \\
\hline 7. e + ${ }^{-} \mathrm{OOCCOO}^{-}=(\mathrm{HO})_{2} \mathrm{CCOOH}+3 \mathrm{OH}^{-}$ & $4.6 \times 10^{7}$ \\
\hline 8. $\mathrm{H}+\mathrm{HOOCCOOH}=(\mathrm{HO})_{2} \mathrm{CCOOH}$ & $3.3 \times 10^{5}$ \\
\hline 9. $\mathrm{H}+\mathrm{HOOCCOO}^{-}=(\mathrm{HO})_{2} \mathrm{CCOOH}+\mathrm{OH}^{-}$ & $1.6 \times 10^{4}$ \\
\hline 10. $\mathrm{H}+\mathrm{OOCCOO}^{-}=(\mathrm{HO})_{2} \mathrm{CCOOH}+2 \mathrm{OH}^{-}$ & $1 \times 10^{4}$ \\
\hline 11. $\mathrm{OH}+\mathrm{HOOCCOOH}=\mathrm{H}_{2} \mathrm{O}+\mathrm{CO}_{2}+{ }^{*} \mathrm{COO}^{-}+\mathrm{H}^{+}$ & $1.4 \times 10^{6}$ \\
\hline 12. $\mathrm{OH}+\mathrm{HOOCCOO}^{-}=\mathrm{H}_{2} \mathrm{O}+\mathrm{CO}_{2}+* \mathrm{COO}^{-}$ & $1.9 \times 10^{7}$ \\
\hline 13. $\mathrm{OH}+{ }^{-} \mathrm{OOCCOO}=\mathrm{OH}^{-}+\mathrm{CO}_{2}+* \mathrm{COO}^{-}$ & $9.7 \times 10^{5}$ \\
\hline 14. $\mathrm{HCOOH}=\mathrm{H}^{+}+\mathrm{HCOO}^{-}$ & $1.8 \times 10^{6}$ \\
\hline 15. $\mathrm{H}^{+}+\mathrm{HCOO}^{-}=\mathrm{HCOOH}$ & $1 \times 10^{10}$ \\
\hline 16. $* \mathrm{COOH}=* \mathrm{COO}^{-}+\mathrm{H}^{+}$ & $4 \times 10^{8}$ \\
\hline 17. $* \mathrm{COO}^{-}+\mathrm{H}^{+}=* \mathrm{COOH}$ & $1 \times 10^{10}$ \\
\hline 18. $\mathrm{OH}+\mathrm{HCOOH}=\mathrm{H}_{2} \mathrm{O}+\mathrm{COOH}$ & $1.3 \times 10^{8}$ \\
\hline 19. $\mathrm{OH}+\mathrm{HCOO}^{-}=* \mathrm{COO}^{-}+\mathrm{H}_{2} \mathrm{O}$ & $1.4 \times 10^{8}$ \\
\hline 20. e $+\mathrm{HCOOH}=\mathrm{H}+\mathrm{HCOO}^{-}$ & $1.4 \times 10^{8}$ \\
\hline 21. $\mathrm{H}+\mathrm{HCOOH}=\mathrm{H}_{2}+\mathrm{COOH}$ & $4.4 \times 10^{5}$ \\
\hline $22.2{ }^{*} \mathrm{COO}^{-}={ }^{-} \mathrm{OOCCOO}^{-}$ & $1 \times 10^{8}$ \\
\hline 23. $\mathrm{O}_{2}+* \mathrm{COOH}=\mathrm{HO}_{2}+\mathrm{CO}_{2}$ & $2 \times 10^{9}$ \\
\hline 24. $\mathrm{H}_{2} \mathrm{O}_{2}+* \mathrm{COOH}=\mathrm{OH}+\mathrm{H}_{2} \mathrm{O}+\mathrm{CO}_{2}$ & $5 \times 10^{7}$ \\
\hline $25.2 * \mathrm{COOH}=\mathrm{HOOCCOOH}$ & $4 \times 10^{8}$ \\
\hline 26. $2 * \mathrm{COOH}=\mathrm{HCOOH}+\mathrm{CO}_{2}$ & $5 \times 10^{8}$ \\
\hline 27. $\mathrm{O}_{2}+* \mathrm{COO}^{-}=\mathrm{O}_{2}+\mathrm{CO}_{2}$ & $2 \times 10^{9}$ \\
\hline $\begin{array}{l}\text { 28. } 2(\mathrm{HO})_{2} \mathrm{CCOOH}=\mathrm{GA}+\mathrm{HOOCCOOH} \\
\text { glyoxylic acid } \mathrm{GA}=\mathrm{OCHCOOH}\end{array}$ & $1 \times 10^{8}$ \\
\hline $29.2(\mathrm{HO})_{2} \mathrm{CCOOH}=\mathrm{DA}$ & $1 \times 10^{8}$ \\
\hline dihydroxycitartaric acid $\mathrm{DA}=\left(\mathrm{C}(\mathrm{OH})_{2} \mathrm{COOH}\right)_{2}$ & \\
\hline 30. $2(\mathrm{HO})_{2} \mathrm{CCOOH}=\mathrm{HOOCCOOH}+2 \mathrm{HCOOH}$ & $1 \times 10^{9}$ \\
\hline 31. $(\mathrm{HO})_{2} \mathrm{CCOOH}+\mathrm{COOH}=\mathrm{HA}$ & $1 \times 10^{9}$ \\
\hline \multicolumn{2}{|l|}{ Dihydroxymalonic acid $=\mathrm{HA}$} \\
\hline 32. $\mathrm{H}_{2} \mathrm{O}_{2}+(\mathrm{HO})_{2} \mathrm{CCOOH}=\mathrm{OH}+\mathrm{H}_{2} \mathrm{O}+\mathrm{HOOCCOOH}$ & $1 \times 10^{5}$ \\
\hline
\end{tabular}

*- indicates for radical products. 


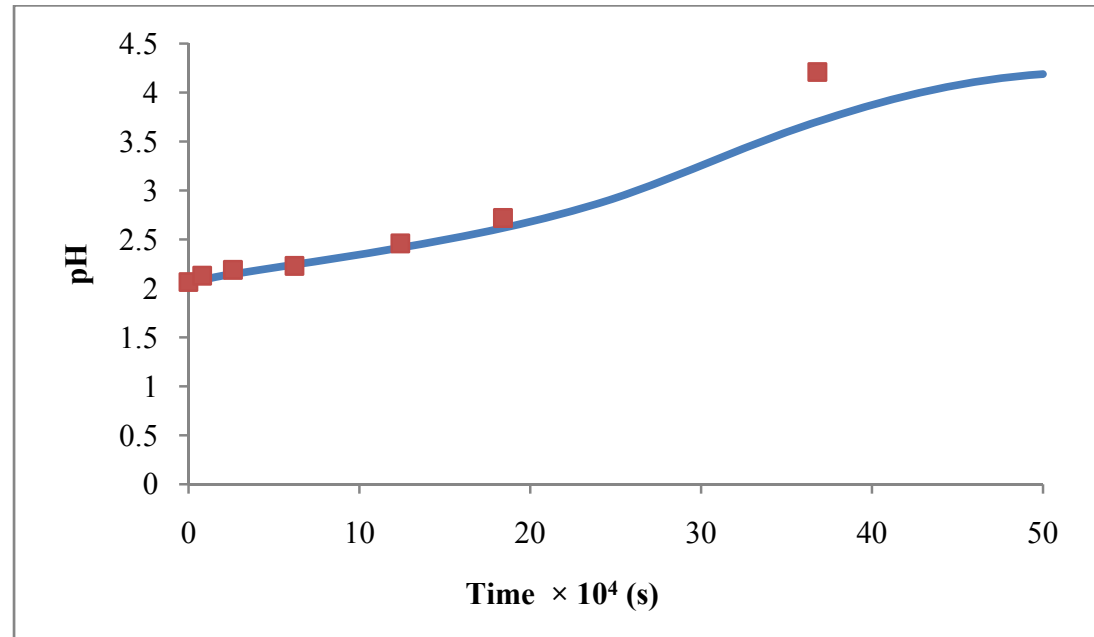

Fig. 1 Kinetics of $\mathrm{pH}$ with the irradiation dose in the radiolysis of aerated oxalic acid solution $\left(1 \times 10^{-2} \mathrm{M}\right) ;$ dose rate $=0.22$ $\mathrm{kGy} / \mathrm{s}$.

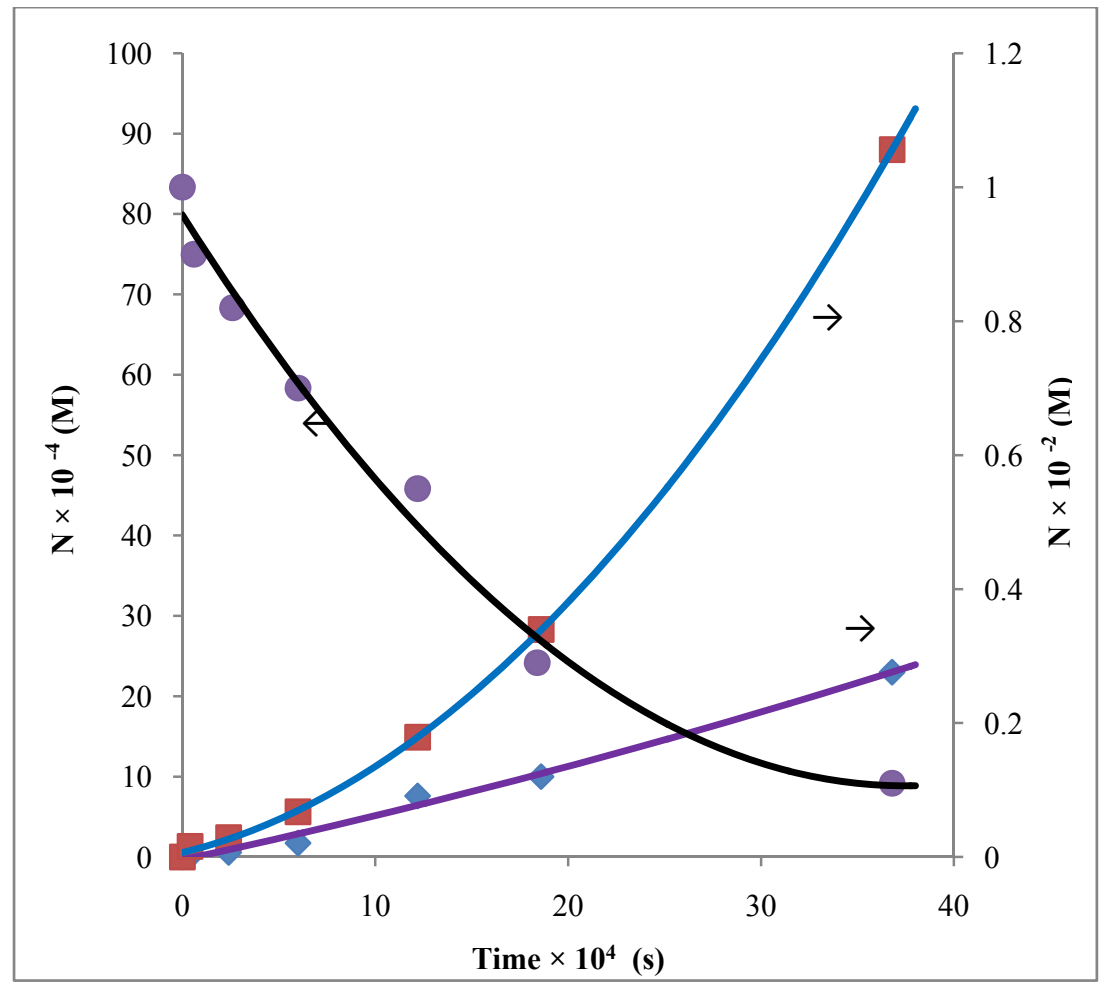

Fig. 2 Kinetics of changes of TOC $(\bullet)$, and concentration of $\mathrm{CO}_{2}(\bullet)$ and $\mathrm{H}_{2}(\bullet)$ with the irradiation dose. Dose rate $=0.22$ $\mathrm{Gy} / \mathrm{s}$; dots are experimental; lines calculated.

The irradiation induced degradation of aerated formic acid solution leads to formation of $\mathrm{CO}_{2}$ as well as increases $\mathrm{pH}$ and decreases COD. The results of $\mathrm{pH}$ changes both experimental and calculated are shown in Fig. 1.

As seen from the Fig. 1 with the increasing of irradiation dose the value of $\mathrm{pH}$ goes up from 2.0 to
4.0. The increased value of $\mathrm{pH}$, most probably, is the result of significant degradation of oxalic acid and its derivatives as well as formation of carbonic acid. It is reported that formation of carbonic acid increases at the $\mathrm{pH} \geq 4.0$ [6]. The considered model enables to compute the concentration of $\mathrm{H}^{+}$ions i.e. the $\mathrm{pH}$ of the solution against to irradiation dose. 
Computed value of $\mathrm{pH}$ was compared with the experimental data in Fig. 1 and they are in a good agreement with each other.

Fig. 2 demonstrates results of experimentally defined changes in TOC (total organic carbon), concentration of $\mathrm{CO}_{2}$ and $\mathrm{H}_{2}$ accumulated during the irradiation. Experimental data are compared with the computed values.

As seen from the Fig. 2, total amount of organic carbon decreases with the irradiation dose. In contrast, the accumulation of $\mathrm{CO}_{2}$ and $\mathrm{H}_{2}$ increases. The kinetics of $\mathrm{CO}_{2}$ formation is characterized induction period of up to dose of approximately $10 \mathrm{kGy} . \mathrm{H}_{2}$ accumulation is in a linear dependence with the irradiation dose. $90 \%$ of organic carbon out of $1 \times 10^{-2}$ $\mathrm{M}$ oxalic acid degrades at the $80 \mathrm{kGy}$. Accumulation of gaseous products raises the safe storage risk of liquid radioactive wastes. But the solubility of $\mathrm{CO}_{2}$ increases with the raising of partial $\mathrm{CO}_{2}$ presser and at $\mathrm{pH} \geq 4$ most of $\mathrm{CO}_{2}$ captures with the water solution due to shifting equilibrium to the right.

\section{Conclusions}

Approximately $90 \%$ oxalic acid and its derivatives are degraded at the dose of $80 \mathrm{kGy}$.

Significant increase in $\mathrm{pH}$ under gamma irradiation occurs until $40 \mathrm{kGy}$ and reaches the maximum value of 4 .

\section{References}

[1] Sato, K., Takmito, K., and Tsuda, S. 1978. "Degradation of Aqueous Phenol Solution by Gamma Irradiation." Environmental Science and Technology 12 (9): 1043-6.

[2] Gordeev, A. V., Ershov, B. Q., and Kosareva, I. M. 2005. "Diffusion-Kinetic Model of Radiation Chemical Conversion of Oxalic Acid and Oxalate Ions in Water Solutions." High Energy Chemistry 39 (4): 250-4.

[3] Jestkova, T. P., Jukova, T. N., and Makarov, I. E. 2011. "The Specifics of Radiolitic Degradation of Oxalic Acid in the Aerated Water Solutions." High Energy Chemistry 45 (2): 115-8.

[4] Kartashova, L. I., Chulkov, V. N., Didenko, O. E., and Pikayev, A. K. 2000, "Hydrogen Peroxide Yields in the Radiolysis of Aerated Aqueous Solutions of Firmic Acid." High Energy Chemistry 34 (6): 467-9.

[5] Buxton, A. W. 1988. "Critical Review of Rate Constants for Reactions of Hydrated Electrons, Hydrogen Atoms and Hydroxyl Radicals in Aqueous Solutions." Phys. Chem. Ref. Data 17 (2): 513.

[6] Carrol, J. J., and Mather, A. E. 1992. "The System Carbon Dioxide-Water." Journal of Solution Chemistry 21: 607-62. 